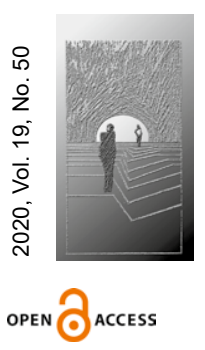

Kerstin Nordlöf

\author{
http://orcid.org/0000-0001-8818-5406 \\ Örebro University
}

School of Law, Psychology and Social Work

Kerstin.Nordlof@oru.se

DOI: 10.35765/hw.1931

\title{
The Dignity of Children Deprived of Liberty and Suspected of Committing Crimes
}

\begin{abstract}
RESEARCH OBJECTIVE: In this article the research objectives are the rights of children deprived of liberty and suspected of having committed crimes in international and regional agreements as well as in Swedish legislations and intended to preserve the child's dignity.
\end{abstract}

THE RESEARCH PROBLEM AND METHODS: The method applied to study their dignity is, on one hand, in the context of international and regional agreements; on the other hand, in the context of Swedish legislations, which are relevant to these children.

THE PROCESS OF ARGUMENTATION: The argument is whether in Sweden children under the age of 15 years deprived of liberty and suspected of having committed crimes are treated in a manner consistent with promoting the child's sense of dignity during the investigation of the crime. These children are of particular interest as they are more vulnerable than adults in the same situation; the spirit of dignity should therefore be more explicitly expressed for them.

RESEARCH RESULTS: The research result confirms that dignity is fundamental for the rights of children as expressed in the studied international and regional agreements and, more specifically, in the CRC Articles 37 and 40.

CONCLUSIONS, INNOVATIONS, AND RECOMMENDATIONS: Swedish legislations still need improvements to preserve the dignity of children, particularly regarding the rights of children under the age of 15 deprived of liberty and suspected of having committed crimes.

\section{$\rightarrow$ KEYWORDS: DIGNITY, CHILDREN, LIBERTY, CRIME}

\section{Introduction}

To elaborate on how dignity as expressed in international and regional agreements is aligned with Swedish legislation and on how these agreements are implemented to ensure the dignity of children under the age of 15 years deprived of liberty and suspected of committing crimes, the following questions must be asked. How is dignity expressed 


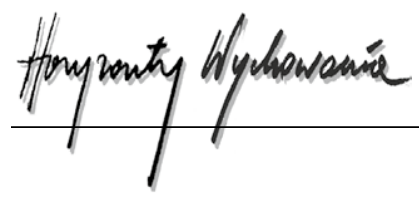

in international and regional agreements relating to the rights of children in this context? How is the dignity of these children preserved in Swedish regulations and how are these regulations implemented? The study focuses on the rights of children deprived of liberty, namely, the presumption of innocence, the right to legal assistance, and the right to an age of criminal responsibility as stated in the Convention on the Rights of the Child (CRC), Articles 37 and 40. When focusing on those particular rights, the fundamental principles of the CRC will also be noted, namely, non-discrimination (Article 2), the best interests of the child (Article 3), the right to development (Article 6), and the right to be heard (Article 12).

To answer these questions and fulfil the present purpose, this article examines international and regional agreements concerning dignity in relation to the rights of children, particularly of children deprived of liberty and suspected of committing crimes. Other materials such as recommendations and court cases are considered in relation to these agreements. Concerning the implementation of these rights in Sweden, Swedish legislation addressing dignity as applicable to children is studied. Legislation concerning children under the age of 15 deprived of their liberty and suspected of committing crimes is of particular interest. Preparatory work for the relevant legislation is studied as are a Supreme Court case, Court of Appeal cases, and the work of legal scholars.

International agreements of interest are the Charter of the United Nations Act of 1945 (No. 32, 1945) and the Universal Declaration of Human Rights of 1948 (UDHR) (UN General Assembly resolution 217A). Other international agreements meriting consideration are: the Declaration of the Rights of the Child of 1959 (G.A. res. 1386 (XIV), 14 U.N. GAOR Supp. (No. 16) at 19, U.N. Doc. A/4354); the International Covenant on Civil and Political Rights of 1966, which entered into force in 1976 (UN General Assembly resolution 2200A (XXI); and the United Nations Standard Minimum Rules for the Administration of Juvenile Justice of 1985 (The Beijing Rules) (UN Doc. A/RES/40/33). The Convention on the Rights of the Child of 1989 (CRC), Articles 37 and 40, are of particular interest. Also important among the international agreements to be studied are the United Nations Guidelines for the Prevention of Juvenile Delinquency of 1990 (The Riyadh Guidelines) (UN General Assembly Resolution 45/112) and the United Nations Rules for the Protection of Juveniles Deprived of their Liberty of 1990 (The Havana Rules) (UN General Assembly Resolution 45/113). In addition to these international agreements, documents that interpret and discuss them will be considered, for example, the work of the Committee on the Rights of the Child (UN General Assembly resolution 44/25), particularly General Comment No. 10 (2007): Children's Rights in Juvenile Justice, 25 April 2007, CRC/C/GC/10.

A regional agreement of interest for this study is the Convention for the Protection of Human Rights and Fundamental Freedoms of 1950 (ECHR) (Rome, 4.XI.1950), as amended by the provisions of Protocol No. 14 (CETS no. 194). Cases from the European Court of Human Rights (ECtHR) concerning children deprived of liberty and suspected of committing crimes are studied. The Charter of the Fundamental Rights of the European Union of 2000 (2000/C 364/01) (ECR) is also of interest, as are cases from 
the Court of Justice of the European Union (CJEU) dealing with this matter. The relevant work of legal scholars will also be examined.

Swedish legislation aligned with international and regional agreements considered in this study are: SFS 1974:152, the Instrument of Government; SFS 1942:740, the Code of Procedure; SFS 1962:700, the Penal Code; SFS 1964:167, the Law with Special Provisions for Young Offenders; SFS 2001:453, the Social Services Act; and SFS 1990:52, the Law with Provisions for Care of Young People.

\section{International Agreements}

In this section, international agreements referring to dignity as such as well as in relation to children deprived of liberty and suspected of committing crimes are studied in chronological order. The first agreement is the Charter of the United Nations, which states in the first part of the preamble that "[w]e the peoples of the United Nations determined to reaffirm faith ... in the dignity ... of the human person." Dignity serves as an interpretative guide to ensure peace, justice, and freedom (Report of the Rapporteur of Commission I/1 UNICO VI, pp. 446-447, Doc. 944 I/1/34(1). Similarly, dignity is addressed in the preamble of the UDHR, which also states that "inherent dignity ... is the foundation of freedom, justice and peace." The Declaration of the Rights of the Child also refers in its preamble to the United Nations Charter and to the people's reaffirmation of "their faith ... in the dignity ... of the human person." Furthermore, the Declaration refers to dignity in relation to children, stating in its Principle 2 that "the child shall enjoy special protection, and shall be given opportunities and facilities, by law and by other means, to enable him to develop physically, mentally, morally, spiritually and socially in a healthy and normal manner and in conditions of freedom and dignity." The International Covenant on Civil and Political Rights refers in its preamble to the Charter of the United Nations and its recognition of the inherent dignity of the human person. In the International Covenant on Civil and Political Rights, dignity is also mentioned in relation to persons suspected of committing crimes. Article 10.3 states that "[a]ll persons deprived of their liberty shall be treated with humanity and with respect for the inherent dignity of the human person," further stating that juveniles should be kept separate from adults. The Covenant also mentions the right to legal assistance in Article 14.3(d).

The following international agreement deals more precisely with children and with children deprived of their liberty and suspected of committing crimes. The Beijing Rules particularly address the treatment of children deprived of liberty and suspected of committing crimes. Dignity is not specifically mentioned but is referred to in its Commentary on Article 2 on the Scope of the Rules and definitions used. Principle 2 of the Declaration of the Rights of the Child, cited above, is mentioned, and it is made clear that the Beijing Rules should follow the formulation of this principle. In other words, the administration of juvenile justice should take place in conditions of dignity. As this international agreement particularly concerns children deprived of liberty and suspected of committing 


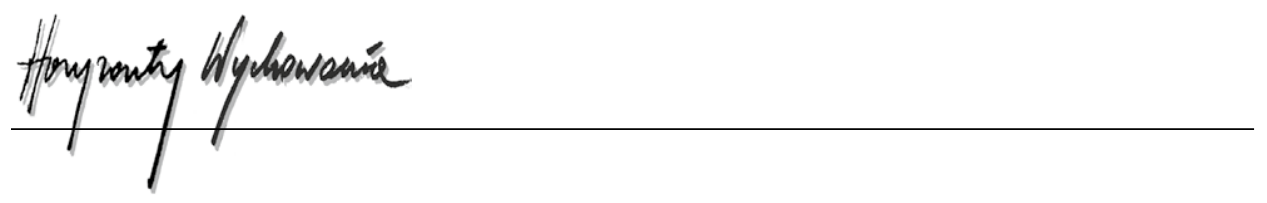

crimes, Rules 4, 7, and 26 of are of special interest for this study. Rule 4, dealing with the age of criminal responsibility, states that "the beginning of that age shall not be fixed at too low an age level, bearing in mind the facts of emotional, mental and intellectual maturity." In its Commentary on Rule 4, the Beijing Rules argues that the age of criminal responsibility is a question of whether a child has sufficient discernment and understanding to be held responsible for an antisocial behaviour. Rule 7 sets forth the rights of juveniles, with the rights of particular interest for this study being the presumption of innocence and the right to legal counsel. The last rule of the Beijing Rules considered here is Rule 26 concerning the objectives of institutional care. In addition to the provision of care, protection, education and vocational skill training, and medical and psychological support, Rule 26 specifies that children should be kept separate from adults, i.e., in separate institutions or in a separate part of an institution that also holds adults.

The CRC refers in its preamble to the Charter of the United Nations and its recognition of the inherent dignity and reaffirmation of its faith in fundamental human rights and in the dignity and worth of the human person. In its preamble, the CRC emphasizes "that the child should be fully prepared to live an individual life in society, and brought up ... in particular in the spirit of ... dignity." According to Article 1, the CRC is applicable to children under the age of 18 . The rights within the Convention are thus of particular interest, as our study deals with children under the age of 15 . Articles 2, 3, 6, and 12 contain the fundamental principles of the CRC and are consequently of interest for this study. Article 2 is about non-discrimination and states that the rights of the Convention apply to all children without any exceptions. It states that in matters that affect children's lives, "States Parties shall respect and ensure the rights set forth in the present Convention to each child within their jurisdiction without discrimination of any kind, irrespective of the child's," for example, national and ethnic origins. Children deprived of liberty and suspected of committing crimes can be children of varied national and ethnic origins. During an investigation of a crime, a child suspect must, according to Article 2, be treated equally regardless of her/his national or ethnic background. Article 3 states that the best interests of the child must be the primary concern when making decisions that may affect the child; specifically, Article 3.1 states that "[i]n all actions concerning children, whether undertaken by public or private social welfare institutions, courts of law, administrative authorities or legislative bodies, the best interests of the child shall be a primary consideration." Obviously, any decision made during a criminal investigation in which the suspect is a child under the age of 15 must make the best interests of that child a primary concern. Article 6 is also of interest, as it makes the States Parties responsible for ensuring the development of the child, which is fundamental when dealing with children deprived of liberty and suspected of committing crimes. The last fundamental principle of the CRC is Article 12, which concerns the right to be heard. When investigating a crime but also when deciding what measures to take for the child, it is of fundamental importance that "the views of the child ... [be] given due weight in accordance with the age and maturity of the child."

Articles 37 and 40 of the CRC specifically deal with the right of children derived of liberty and suspected of committing crimes. Article 37 states that no child should be 
subjected to inhuman or degrading treatment. Furthermore, no child should be deprived of her/his liberty unlawfully or arbitrarily, and if the child is deprived of her/his liberty, this must be done for the shortest period of time. Dignity is specifically mentioned in Article $37(\mathrm{c})$, which states that a child deprived of her/his liberty must "be treated with humanity and respect for the inherent dignity of the human person." Furthermore, the child must be treated in a manner that takes into account the needs of a child of her/his age. This also entails that the child should be kept separate from adults. Article 37(d) states that a child deprived of her/his freedom must have access to legal or other appropriate assistance and the right to challenge the legality of the deprivation of her/his liberty as well as a prompt decision regarding such action. Article 40 also explicitly refers to dignity. Article 40.1 states that a child suspected of committing a crime has a right to be "treated in a manner consistent with the promotion of the child's sense of dignity and worth." Attention also must be paid to the age of each individual child, as being treated in this way will strengthen the child's own respect for the rights of all human beings as well as for the fundamental freedoms of others. Such treatment will also promote the child's reintegration and ability to take a constructive role in society. Article 40.2(b)(i) states that a child suspected of committing a crime must be presumed innocent until proven guilty, while Article 40.2(b)(ii) further states that the child must also be provided with legal or other appropriate assistance during the investigation of the crime that the child is suspected of having committed. Article 40.3 emphasizes that the states must establish "laws, procedures, authorities and institutions specifically applicable to children" suspected of committing crimes. Article 40.3(a) underlines that an age of criminal responsibility should be established by the States Parties. The CRC does not stipulate a certain age but only that a minimum age should be established. The United Nations Committee on the Rights of the Child has asserted, in communication with various states regarding this issue, that the age should be above 14 (General Comment No. 10 (2007): Children's Rights in Juvenile Justice, 25 April 2007, CRC/C/GC/10). Regarding this issue, the Child Rights International Network (CRIN) argues that the Committee on the Rights of the Child should, in the General Comments of the Committee, encourage the States Parties to raise the minimum age towards 18 (CRIN, Comments on the Draft revised General Comment No. 10 (2007) on children's rights in juvenile justice, 2019). This approach is supported by research indicating that the human brain is typically not fully developed before the age of 25 , particularly when it comes to assessing risks (Carlin, 2007).

Of relevance for its implementation and interpretation, the CRC is the work of the Committee on the Rights of the Child. The last concluding observation by the Committee concerning Sweden is from 2015 (CRC/C/SWE/CO/5). Of interest for this study, the Committee recommends legislative measures to be taken and promotes awareness of the meaning and practical application of issues relating to three of the fundamental principles of the CRC: non-discrimination, the best interests of the child, and respect for the views of the child. In Section 20 of the concluding observation, the Committee recommends particularly that Sweden "take measures to strengthen ... and to ensure the effective implementation of legislation recognizing the right of the child to be heard 


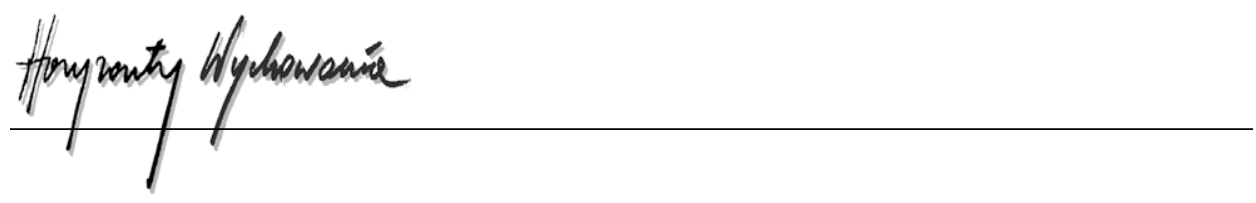

in relevant legal proceedings, including by establishing systems and/or procedures for social workers and courts to comply with the principle."

The Riyadh Guidelines do not specifically mention dignity, although they do refer, for example, to the CRC, which mentions dignity in its preamble and in Articles 37 and 40. The Riyadh Guidelines focus on preventing children from committing crimes and are divided into: fundamental principles, scope of guidelines, general prevention, socialization processes, family, education, community, mass media, social policy, legislation and juvenile justice administration, research, and policy development and coordination. The Havana Rules refer to dignity in several articles concerning the treatment of juveniles in the care of institutions where inmates require permission in order to leave. Rule 29 states that juveniles shall be kept separate from adults. In cases in which juveniles may be held together with adults, the adults must be carefully selected and such shared detention should be part of a programme that has been proved beneficial for the juveniles.

\section{Regional Agreements and Court Cases}

Dignity is not explicitly mentioned in the ECHR, though its Protocol No. 13 of 2002 concerning the abolition of the death penalty in all circumstances does mention dignity, nor are children explicitly mentioned. Still, the Convention is as applicable to children as it is to adults, as Article 1 states that everyone within the jurisdiction of the countries that have ratified the Convention should ensure the rights and freedoms set forth in the ECHR. It is consequently of interest to study ECtHR cases in which the issues relate to children deprived of their liberty and suspected of committing crimes.

The age of criminal responsibility has been discussed by the ECtHR in two cases: $T$ v. United Kingdom (Application No. 24724/94) and V v. United Kingdom (Application No. 24888/94). The issue was whether the trial of two ten-year-old children, who were accused of having murdered a small child, had violated Article 3 of the ECHR, which states that "[n]o one shall be subjected to torture or inhuman or degrading treatment or punishment." The Court found that neither their age, the circumstances under which the trial took place, nor that they were sentenced to imprisonment for an indeterminate period of time meant that they had been exposed to inhuman or degrading treatment (Danelius, 2015). Still, the United Kingdom had not guaranteed the two sentenced boys a fair trial considering the prerequisite for release, even though they had been deprived of their freedom for six years. This was found by the Court not to be in accordance with ECHR Article 5.4, which states that "[e]veryone who is deprived of his liberty by arrest or detention shall be entitled to take proceedings by which the lawfulness of his detention shall be decided speedily by a court and his release ordered if the detention is not lawful." The Court also found that the United Kingdom had not fulfilled the conditions in Article 6 that a court must decide the minimum time a sentenced person must be deprived of his/her freedom, not a minister, as was the case when $T$ and $V$ were tried. Article 6.1 states that "[i]n the determination of his civil rights and obligations or of any criminal 
charge against him, everyone is entitled to a fair and public hearing within a reasonable time by an independent and impartial tribunal established by law." Furthermore, the Court found that the two boys had not been able to take part in the trial in an effective way, in violation of Article 6.1.

In a more recent case, Blokhin v. Russia (Application no. 47152/06), with judgment handed down in 2016, a 12-year-old boy was detained in a centre for juvenile offenders for 30 days because he "had committed a delinquent act - extortion - and it was necessary to 'correct his behaviour' and prevent him from committing further delinquent acts." The ECtHR found that there had been a violation of Articles 3 and 5.1. Relating to Article 3 , the child had not received necessary medical treatment at the centre. Concerning Article 5, the detention of the child in the detention centre had not had any legitimate purpose and had therefore been arbitrary. There had also been a violation of Articles 6.1 and 6.3(c) and (d), as the child's defence rights were restricted and legal assistance was lacking during the questioning by police, which were incompatible with the guarantees of the Article. In the judgment, the ECtHR wrote: "In view of the particular vulnerability of children and taking into account their level of maturity and intellectual and emotional capacities, the Court stresses in particular the fundamental importance of providing access to a lawyer where the person in custody is a minor" (Section 199). The Court also emphasizes the importance of minors, without any exceptions, being guaranteed procedural rights such as the presumption of innocence. This includes situations when the minor may be deprived of her/his liberty as a protective measure for the child her/ himself (Section 196). The Court concludes that "adequate procedural safeguards must be in place to protect the best interests and well-being of the child, certainly when his/ her liberty is at stake. To find otherwise would be to put children at a clear disadvantage compared with adults in the same situation" (Section 219). The ECtHR refers in its arguments to several regional recommendations of the Committee of Ministers: No. R (87) 20 on social reactions to juvenile delinquency; $\operatorname{Rec}(2003) 20$ concerning new ways of dealing with juvenile delinquency and the role of juvenile justice; and $\mathrm{CM} / \operatorname{Rec}(2008) 11$ on the European Rules for juvenile offenders subject to sanctions or measures. The Guidelines by the Committee of Ministers of the Council of Europe on child-friendly justice, 17 November 2010, are mentioned. International agreements are also referred to, for example, the CRC, particularly Articles 3, 37, and 40. General Comments by the Committee on the Rights of the Child are cited, such as No. 9 (2006) (27 February 2007, UN Doc. CRC/C/GC/9) and No. 10 (2007) (25 April 2007, UN Doc. CRC/C/GC/10). There are also references to the Beijing Rules, Havana Rules, and Riyadh Guidelines.

The Charter of the Fundamental Rights of the European Union (ECR) refers to dignity in its preamble, which states that "the Union is founded on the indivisible, universal values of human dignity." Furthermore, Article 1 is devoted to dignity and states that "[h] uman dignity is inviolable. It must be respected and protected." Article 24 deals with the rights of the child. Of interest for this study is the right of children to express their views freely and that those views "shall be taken into consideration on matters which concern them in accordance with their age and maturity" (Article 24.1). Furthermore, "[i]n 


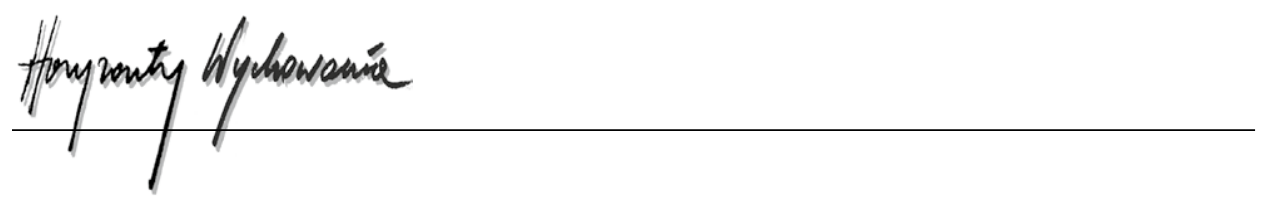

all actions relating to children, whether taken by public authorities or private institutions, the child's best interests must be a primary consideration" (Article 24.2).

Of relevance to this study is Case C367/16 Piotrowski from the CJEU concerning the application of a European arrest warrant in relation to minors and, more specifically, the grounds for mandatory non-execution. The Court concludes that European arrest warrants are not applicable to children who have not reached the age of criminal responsibility under the law of the executing Member State. It is up to the judicial authority of the executing Member State to verify whether the child has reached this age.

\section{Swedish Legislations and Court Cases}

This section will describe the measures to be taken when a child under the age of 15 is deprived of liberty and suspected of committing a crime as well as the rights of the child in such a situation. The purpose is to give context, as this article examines the preservation of dignity for these children and the implementation of the rights specified in international and regional agreements for children in such situations in Sweden.

Dignity is mentioned in the Swedish constitution. In SFS 1974:152, Chapter 1 Article 2, dignity is mentioned in relation to the exercise of public power, namely, that it "shall be exercised with respect for the equal worth of all and the liberty and dignity of the individual." The same Article states concerning children that "[t]he public institutions shall promote ... the rights of the child to be safeguarded."

In Sweden, a person who has committed an offence becomes criminally responsible at the age of 15 . (SFS 1962:700 Chapter 2 Article 6). A child under that age may commit offences but will not be considered responsible in the sense that she/he can be charged and, if found guilty, incur a sanction. Still, even though not being charged, the child can be interviewed by the police. In such situations, the suspect child has the rights of an accused person, for example, the presumption of innocence, of which the right to legal assistance is part (Nordlöf, 2013). Interventions interfering with personal integrity are still possible, though Social Services have the main responsibility to determine whether the child is in need of their assistance (SFS 1964:167 Article 31 to 38).

In Sweden the issue was raised as to whether uncertainty about the age of the suspect constitutes legal grounds for using means of compulsion. Criminal cases in 2015 and 2016 raised the issue, more precisely, the legal grounds for the use of body search, as age of criminal responsibility is a condition for punishing a person who has committed a crime. The accused in those cases were all men who had arrived in Sweden in connection with the wave of refugees in autumn 2015 (The Court of Appeal, Svea hovrätt B 10485:15; the Court of Appeal, in Skåne and Bleking B 329-15; the Court of Appeal, for Västra Sverige B 1672-15; the Court of Appeal, Svea hovrätt B 905-13; the Court of Appeal, Göta hovrätt B 1325-05; and the Court of Appeal, Svea hovrätt B 232-16). The Supreme Court concluded in 2016 that current legislation regarding body search did permit its use to determine the age of the suspects, who, in some of the cases, had claimed to be under the age 
of criminal responsibility (The Supreme Court Ö 3278-16). In 2017, a legal basis for body search due to uncertainty as to the age of the suspect was implemented (Government Bill 2016/17:165, SFS 1942:470 Chapter 28 Article 12(3)). The extension of means of compulsion to children may have a negative impact on gender and diversity, in the sense that men of foreign background commit more crimes than do women and men born in Sweden.

A child under the age of 15 cannot be arrested, though she/he can be seized by the police on suspicion of having committed a crime. After a child under the age of 15 has been seized, she/he will then be taken to a police station for interrogation (SFS 1942:740 Chapter 24 Art. 7). Like anyone else, a person seized by the police has a right to be informed of what crime she/he is suspected of having committed, and of the reasons why she/he is being seized (SFS 1942:740 Chapter 24 Art. 9). She/he can also be seized by anyone if the penalty for the crime is imprisonment, and if the child is caught while committing the crime. Such situations are rare, but if they arise, the child has to be promptly handed over to the nearest police station (SFS 1964:167 Article 35). A child under the age of 15 can also be held at a police station if she/he was at the scene of a crime and the police have reasons to interrogate her/him. The child might also be asked to come to the police station for interrogation (SFS 1942:740 Chapter 23 Articles 7 and 8).

At the police station, the police or the prosecutor must immediately decide whether the child suspected of committing a crime should be released or interrogated. Under no circumstances is she/he to be placed in a cell or similar confinement (SFS 1964:167 Article 35). The child cannot stay at the police station for more than three hours. If it is of particular importance to the investigation, the child may be asked to stay for another three hours at the police station (SFS 1942:740 Chapter 23 Article 9). The child is free to leave the police station when the interrogation is over; however, to enable parents, other relatives of the child, or a social worker to come and pick up the child, the child can be kept at the police station for another three hours after the interrogation is finished (SFS 1964:167 Articles 14 and 35).

If the police suspect that a child has committed a crime, they can carry out a crime investigation. In situations in which the child is under suspicion of having committed a crime for which the sentence is at least one year of imprisonment, the police can start an investigation without initiation by Social Services (SFS 1964:167 Article 32). As a child under the age of 15 cannot be held criminally responsible, the purpose of the investigation is to find out whether the child is in need of care in accordance with SFS 2001:453 or SFS 1990:52: the former concerns care on a voluntary basis, while the latter concerns compulsory care. Criminality can be one reason for the enforcement of care. If the child requires compulsory care, she/he can be placed in an institution with locked facilities for young offenders, both those convicted of crimes and those under the age of criminal responsibility. The age of persons in such institutions ranges from under 15 to 21 (Nordlöf, 2012). Still, the best interests of the child must be taken into account when dealing with children (SFS 2001:453 Chapter 1 Article 2).

If Social Services are of the opinion that an investigation under police authority is important in order to determine whether the child is in need of social services, they can 


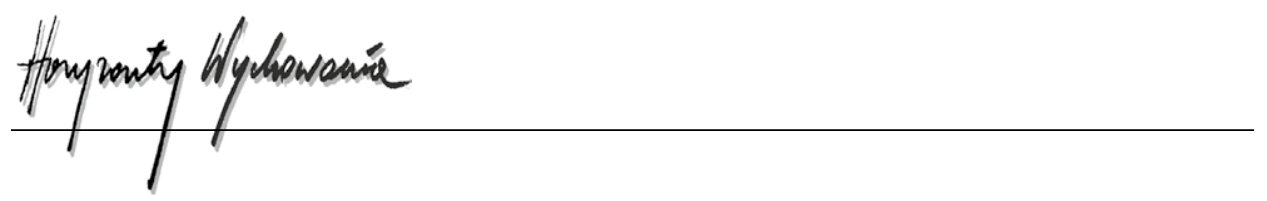

ask the police to carry out an investigation. Reasons for investigation can include assessment of the harm to the health or development of the child caused by the crime, or the child having committed crimes multiple times. An investigation may also be conducted to clarify whether someone aged 15 or older has been involved in the crime, to find goods that are missing due to the crime, or for other reasons of special importance due to public or individual interests (SFS 1964:167 Article 32). If the child is under the age of 12 , an investigation by the police can only take place if there are special reasons.

A child suspected of committing a crime has to be interrogated by police officers specially trained in interrogation methods for children. If a prosecutor is involved, she/ he must also be specially trained in dealing with issues concerning juvenile delinquency. The parents must be informed promptly that the child is suspected of committing a crime, and be informed of the time of the interrogation of the child. This does not mean that the parents have a right to be present at the interrogation. The parents cannot be present at the interrogation if their presence is considered to harm the investigation, or there is suspicion that the parents may assault the child. If the parents are not able to be present, another person has to be informed for the purpose of providing comfort to the child (SFS 1964:167 Articles 32 and 33; SFS 1942:740 Chapter 23 Article 10; Nordlöf, 2012). The aim is to have adults present to care for the child. Social Services must always be informed when a child is under suspicion of having committed a crime. A social worker must also be present at the interrogation of the child (SFS 1964:167 Article 34; Nordlöf, 2012).

A police investigation in which the suspect is a child under the age of 15 must be carried out with special urgency and be concluded as soon as possible. There is a three-month time limit, which can be exceeded if necessary depending on the nature of the investigation or on other special circumstances (SFS 1964:167 Article 32).

\begin{abstract}
A legal counsel for the child can be appointed by the court after a request is made by the prosecutor or the parents. If the police initiate an investigation and it is not evident that the child needs a legal counsel, the court cannot appoint a legal counsel. If Social Services ask the police to conduct an investigation, there must be a special reason for appointing a legal counsel. There is consequently no absolute right to a legal counsel for a child under the age of 15 and suspected of committing a crime. Even if parents or another guardian as well as a representative of Social Services are present, they cannot replace or fulfil the rights to a legal counsel that Swedish legislation lacks (SFS 1964:167 Article 32; Nordlöf, 2013).
\end{abstract}

A child under the age of 15 and under suspicion of having committed a crime can be exposed to means of compulsion, though there should be special reasons for using such means. Means of compulsion refer to the seizure of goods, search of physical spaces, body search, as well as taking photos and fingerprints of the child. If the child is suspected on reasonable grounds of having committed a crime, and the punishment for the suspected crime is at least one year of imprisonment, then she/he can be exposed to body examination. However, this is not sufficient justification, and such means of compulsion can only be used when they are of particular importance in clarifying the circumstances 
of the crime. A body examination can only be conducted by medical staff. If other persons are present, they must be of the same sex as the child, unless the examination consists of taking a blood sample, administering an alcohol test, or taking a saliva sample for DNA analysis (SFS 1964:167 Article 36, 36a and 36b); those means of compulsion should be enforced restrictively. The possibility of conducting body examination was introduced in 2010 and extended in 2017 to be applicable in situations of uncertainty as to the age of the suspect, which might be considered in contradiction to the protections provided in the CRC. Children under the age of 15 require special consideration concerning their personal integrity due to their vulnerability during a sensitive period of their development (Nordlöf, 2012).

As mentioned previously, a child under the age of 15 cannot be charged. However, there is still the possibility of letting a court try the evidence of the crime in situations in which the evidence is in the public interest, for example, if the case has been exposed in the media. The initiative to try the evidence must come from Social Services, the National Board of Health and Welfare, or the parents of the child under suspicion of having committed a crime. After such a request, the prosecutor will ask the court to consider the evidence. This measure has only been employed in a few cases (SFS 1964:167 Article 38; SFS 1942:740 Chapter 28 Article 12(3); Nordlöf, 2012).

\section{Discussion}

The purpose of this study has been to elaborate on how the dignity of children, particularly the dignity of those under the age of 15 deprived of liberty and suspected of committing crimes and treated in international and regional agreements, is safeguarded in Swedish legislation as well as implemented. The focus has been on CRC Articles 37 and 40 , more precisely, the rights of children deprived of liberty, the presumption of innocence, the right to legal assistance, and the age of criminal responsibility. This alignment of Swedish legislation with international and regional agreements takes account of the fundamental principles of the CRC: non-discrimination (Article 2), the best interests of the child (Article 3), the right to development (Article 6), and the right to be heard (Article 12).

Study of international and regional human rights agreements reveals an emphasis on human dignity and its importance for freedom, justice, and peace, as expressed in their preambles. Some of these agreements specify dignity in relation to children, particularly those agreements that deal with the rights of children deprived of liberty and suspected of committing crimes. Swedish legislation applicable to children under the age of $15 \mathrm{de}-$ prived of liberty and suspected of committing crimes makes no reference to the dignity of the child. Still, in the Swedish constitution, more precisely, SFS 1974:152 Chapter 1 Article 2, dignity is referred to in relation to the exercise of public power, namely, that it "shall be exercised with respect for the equal worth of all and the liberty and dignity of the individual." We therefore conclude that any decisions made by public authorities such as Social Services, the police, and the prosecutor and relating to children under 


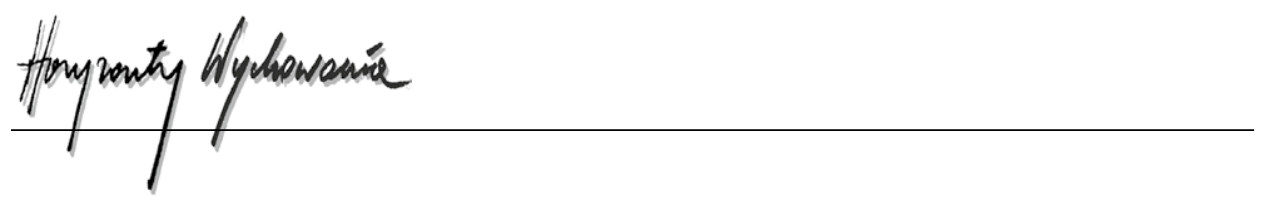

the age of 15 deprived of liberty and suspected of committing crimes must take account of the dignity of the child. Supporting this conclusion are Articles 37 and 40 and the four fundamental principles of the CRC, which have had the status of legislation in Sweden since 2020. Still, the lack of any direct reference to the dignity of the child in other Swedish legislation applicable to children in such situations is grounds for criticism.

In the following, the dignity of children deprived of liberty and suspected of committing crimes will be discussed specifically in relation to the rights of children deprived of liberty, the presumption of innocence, the right to legal assistance, and the age of criminal responsibility. The discussion will also relate to the four fundamental principles of the CRC, namely, non-discrimination, the best interests of the child, the right to development, and the right to be heard.

\section{The rights of children deprived of liberty}

Children, particularly children under the age of 15, are more vulnerable than others are, so they have to be protected in various ways from, for example, negative influences (Sandberg, 2015). In several international agreements, being kept separate from adults has therefore long been a right of children deprived of liberty. In the studied international agreements, this right is first mentioned in the Beijing Rules. Concerning care in institutions, Rule 26 states that children should be kept separate from adults, meaning in separate institutions or in a separate part of an institution that also holds adults. This is also emphasized in the International Covenant on Civil and Political Rights in Article 10.3, stating that juveniles deprived of their liberty shall be kept separate from adults. Article 37 (c) of the CRC elaborates on the rights of children deprived of liberty, stating that they shall be kept separate from adults except if it is considered in their best interests not to be kept separate from adults. Rule 29 of the Havana Rules also states the principal rule that, with certain exceptions, juveniles must be kept separate from adults.

The relevant Swedish legislation concerning the institutional care of children suspected of committing crimes is SFS 1990:52. This law sets forth the requirements for the enforcement of compulsory care. Criminality can be one reason for the enforcement of such care. If the child is in need of compulsory care, she/he can be placed in an institution with locked facilities for young offenders, both those convicted of crimes and those under the age of criminal responsibility. The age of the children and young persons in such institutions ranges from under 15 to adults up to the age of 21 (Nordlöf, 2012). It is obvious that Swedish legislation concerning the rights of children deprived of liberty to be separated from adults does not fulfil the requirements stated in international agreements, particularly in CRC Article 37(c). Swedish legislation may also be considered to be in contradiction to the best interests of the child, which must be taken into account when dealing with children, as stated in SFS 2001:453 Chapter 1 Article 2 and in CRC Article 3. The importance of keeping children separate from adults is also in accordance with the fundamental principle of the child's right to development, as expressed in CRC Article 6. 


\section{The presumption of innocence}

The presumption of innocence is fundamental to carrying out an objective crime investigation and to guaranteeing a fair trial, being stated in the Universal Declaration of Human Rights Article 1 and in the International Covenant on Civil and Political Rights Article 14. Rule 7 of the Beijing Rules recognizes the presumption of innocence also for children suspected of committing crimes. Swedish legislation concerning children under the age of 15 suspected of committing crimes includes no articles concerning the presumption of innocence. Relevant Swedish legislation concerning persons under suspicion of having committed crimes, regardless of their age, also does not address the presumption of innocence, although it is applied as a fundamental procedural safeguard. Still, the presumption of innocence is mentioned in ECHR Article 6.2, ECR Article 48(1), and CRC Article 40.2(b)(i), which all have the status of legislation in Sweden. However, particularly for those under the age of 15 and suspected of committing crimes, and perhaps for the first time in contact with legal authorities, the importance of implementing fundamental safeguards such as the presumption of innocence should particularly be stressed in legislation applicable to children in this situation. It would also be in accordance with the fundamental principles of the CRC, namely, the best interests of the child (Article 3) and the right to be heard (Article 12).

\section{The right to legal assistance}

The right to legal assistance is part of the presumption of innocence. The right to legal assistance for children under the age of 15 and suspected of committing crimes is set forth in Rule 7 of the Beijing Rules, stating that it is one of the basic procedural safeguards. The right is also recognized in other international agreements, such as UDHR Article 11 and the International Covenant on Civil and Political Rights Article 14.3(d). In the regional agreements, it is found in ECHR Article 6.3(c) and in ECR Article 47. In the two cases $T$ v. United Kingdom (Application No. 24724/94) and V v. United Kingdom at the ECtHR, it was found that there had been violation of ECHR Article 6.1. This decision was based on the fact that the two boys had not been able to take part in the trial in an effective way. Although it is not directly related to the right to legal assistance, CRC Article 2 is relevant not only to obtaining a fair trial but also to the right of children to be heard. A more recent case directly related to ECHR Article 6.3(c) is Blokhin v. Russia in 2016. The Court found that the absence of legal assistance during the questioning by police was incompatible with the guarantees of ECHR Article 6.3(c). CRC Article 40.2(b) (ii) obliges the States Parties in particular to ensure that the child suspect shall have legal or other appropriate assistance. This is akin to the presumption of innocence part of the recognition of States Parties to the Convention that "every child alleged as, accused of, or recognized as having infringed the penal law [is] to be treated in a manner consistent with the promotion of the child's sense of dignity" (CRC Article 40.1). The right 


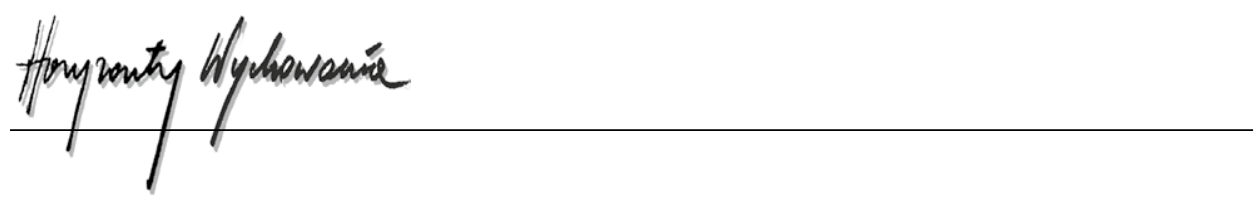

to legal assistance is also part of the child's right to be heard (Article 12), one of the four fundamental principles of the CRC. In Swedish legislation, the right to legal assistance of children under the age of 15 suspected of committing crimes is addressed in SFS 1964:167 Article 32(a). The right to legal assistance varies depending on whether the police or Social Services take the initiative to begin a criminal investigation. If the police initiate an investigation and it is not evident that the child needs a legal counsel, the court cannot appoint a legal counsel. If Social Services ask the police to conduct an investigation, there must be a special reason for appointing a legal counsel. There is consequently a limitation on the right to legal assistance. Even if other persons such as parents and representatives of Social Services are involved in the case, they cannot be considered substitutes for legal assistance. In this, Swedish legislation has failed to fulfil its obligations as stated in international agreements concerning legal assistance for children, who, compared with others, are very vulnerable.

\section{The age of criminal responsibility}

The age of criminal responsibility is crucial for the enforcement of penal sanctions. The age of criminal responsibility is mentioned in international agreements that particularly deal with children suspected of committing crimes, namely, Beijing Rules Rule 4 and CRC Article 40.3(a): the former refers to the emotional, mental, and intellectual maturity of children when determining the age of criminal responsibility, while the latter cites the importance of imposing a lower age of criminal responsibility. The United Nations Committee on the Rights of the Child has asserted that the age should be above 14. CRIN argues that the Committee on the Rights of the Child should, in its General Comments, encourage the States Parties to raise the minimum age towards 18. This approach is supported by research indicating that a human's brain is typically not fully developed before the age of 25, particularly when it comes to assessing risks. The issue of age of criminal responsibility was discussed by the ECtHR in the two cases $T$ v. United Kingdom and $V v$. United Kingdom. Concerning the age of the two boys, which was ten, who were guilty of having murdered a child, the Court found that neither their age nor other circumstances meant that they had been exposed to inhuman or degrading treatment, as stated in ECHR Article 3. The age of criminal responsibility has also been discussed by the CJEU in Case C367/16 Piotrowski, but in relation to the European arrest warrant. The Court concluded that the European arrest warrant is not applicable to children who have not reached the age of criminal responsibility under the law of the executing Member State. Furthermore, it is up to the judicial authority of the executing Member State to verify whether the child has reached this age. The verification of the age of a child, which is of relevance in order to claim that the person is criminally responsible, has been an issue in Sweden. According to SFS 1962:700 Chapter 2 Article 6, criminal responsibility is applied from the age of 15 . In cases in which the age of the suspect was unclear, the issue was whether it was possible to use means of compulsion in order to 
estimate the age of the person. The accused in those cases were all men who arrived in Sweden with the wave of refugees in autumn 2015. The Supreme Court found that such compulsion was not allowed according to the legislation current as of 2016. In 2017, the legislation was changed to allow the use of a means of compulsion, namely, body search, for the purpose of estimating the age of the suspect. The extension of means of compulsion to apply to children may have a negative impact on gender and diversity, in the sense that men of foreign background commit more crimes than do women and men born in Sweden. The age of criminal responsibility is of fundamental importance from many perspectives, particularly in implementing the four fundamental principles of the CRC: non-discrimination (Article 2), the best interests of the child (Article 3), the right to development (Article 6), and the right to be heard (Article 12).

\section{REFERENCES}

International agreements

The Charter of the United Nations Act 1945, No. 32, 1945.

The Universal Declaration of Human Rights of 1948, UN General Assembly resolution 217 A.

The Declaration of the Rights of the Child of 1959, G.A. res. 1386 (XIV), 14 U.N. GAOR Supp. (No. 16) at 19, U.N. Doc. A/4354.

The International Covenant on Civil and Political Rights of 1966, UN General Assembly resolution 2200A (XXI).

The International Covenant on Economic, Social and Cultural Rights of 1966, UN General Assembly resolution $2200 \mathrm{~A}(\mathrm{XXI})$.

The United Nations Standard Minimum Rules for the Administration of Juvenile Justice of 1985 (The Beijing Rules), UN Doc. A/RES/40/33.

The Convention on the Rights of the Child of 1989, UN General Assembly resolution 44/25.

The United Nations Guidelines for the Prevention of Juvenile Delinquency (the Riyadh Guidelines) of 1990, UN General Assembly Resolution 45/112.

The United Nations Rules for the Protection of Juveniles Deprived of their Liberty (the Havana Rules), of 1990, UN General Assembly Resolution 45/113.

The third Optional Protocol on a Communications Procedure of 2011, UN General Assembly resolution A/RES/66/138.

\section{Regional agreements}

The Convention for the Protection of Human Rights and Fundamental Freedoms of 1950 (ECHR) (Rome, 4.XI.1950, amended by the provisions of Protocol No. 14 (CETS no. 194).

The Charter of the Fundamental Rights of the European Union (2000/C 364/01) (ECR).

\section{Swedish legislations}

SFS 1942:740 the Code of Procedure.

SFS 1962:700 the Penal Code.

SFS 1964:167 the Law with Special Provisions for Young Offenders.

SFS 1974:152 the Instrument of Government.

SFS 1990:52 the Law with Provisions for Care of Young People.

SFS 2001:453 the Social Services Act. 


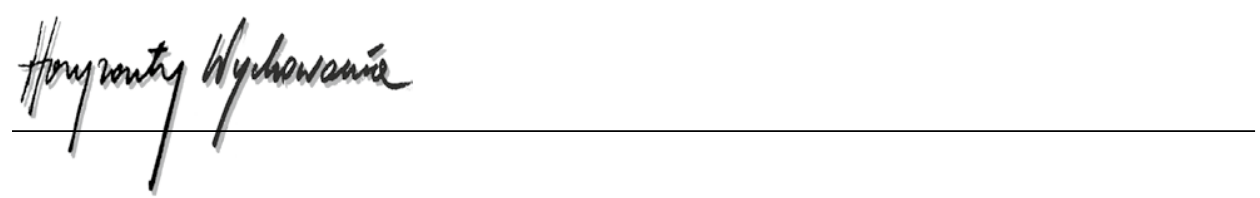

Government Bill 2017/18:186. Inkorporering av FN:s konvention om barnets rättigheter.

Government Bill 2016/17:165.

Court cases

The European Court of Human Rights (ECtHR)

$T$ v. United Kingdom - Application No. 24724/94.

$\checkmark v$. United Kingdom - Application No. 24888/94.

Blokhin v. Russia - Application no. 47152/06).

The Court of Justice of the European Union (CJEU)

Case C367/16 Piotrowski.

The Court of Appeal

The Court of Appeal, Svea hovrätt B 10485:15.

The Court of Appeal, in Skåne and Bleking B 329-15.

The Court of Appeal, for Västra Sverige B 1672-15.

The Court of Appeal, Svea hovrätt B 905-13.

The Court of Appeal, Göta hovrätt B 1325-05.

The Court of Appeal, Svea hovrätt B 232-16.

The Supreme Court

The Supreme Court Ö 3278-16.

Reports

Report of the Rapporteur of Commission I/1 UNICO VI, pp 446-7, Doc. 944 I/1/34(1.).

Work of Human Rights Committee, the Committee on the Rights of the Child and Organisations

General Comment No. 35 of the Human Rights Committee, dated 16 December 2014 (CCPR/C/ $\mathrm{GC} / 35$ ).

General Comment No. 9 (2006) of the Committee on the Rights of the Child, dated 27 February 2007 (CRC/C/GC/9).

General Comment No. 10 (2007): Children's Rights in Juvenile Justice, 25 April 2007, CRC/C/ $\mathrm{GC} / 10$.

The Child Rights International Network, Comments on the Draft revised General Comment No. 10 (2007) on children's rights in juvenile justice. 2019.

www.ohchr.org/_layouts/15/WopiFrame.aspx?sourcedoc=/Documents/HRBodies/CRC/GC10/ CRIN.docx\&action=default\&DefaultttemOpen=1 (Accessed 26 September 2019).

Concluding observation by the Committee concerning Sweden 2015 (CRC/C/SWE/CO/5).

\section{Recommendations and Guidelines}

Recommendation No. R (87) 20 on social reactions to juvenile delinquency, adopted by the Committee of Ministers on 17 September 1987.

Recommendation $\operatorname{Rec}(2003) 20$ of the Committee of Ministers to member states concerning new ways of dealing with juvenile delinquency and the role of juvenile justice, adopted on 24 September 2003.

Recommendation $\mathrm{CM} / \operatorname{Rec}(2008) 11$ on the European Rules for juvenile offenders subject to sanctions or measures, adopted by the Committee of Ministers on 5 November 2008.

The Guidelines of the Committee of Ministers of the Council of Europe on child friendly justice, adopted by the Committee of Ministers on 17 November 2010 


\section{BIBLIOGRAPHY}

Carlin, M. (2007). Hjärnan fullvuxen först vid 25. Svenska Dagbladet, 5 October. Retrieved from: https://www.svd.se/hjarnan-fullvuxen-forst-vid-25 (access: 26.11.2019).

Danelius, H. (2015). Mänskliga rättigheter i europeisk praxis. 5 ed. Stockholm: Norstedts Juridik. Nordlöf, K. (2012). Unga lagöverträdare $i$ social-, straff- och processrätt. Malmö: Studentlitteratur. Nordlöf, K. (2013). Oskuldspresumtionen - en utopi för minderåriga barn misstänkta för brott. In K. Nordlöf (ed.), Argumentation i Nordisk Straffrätt. Norstedts Juridik.

Sandberg, K. (2015). The Convention on the Rights of the Child and the vulnerability of children, Special Issue: Vulnerability of Children within International Law. Nordic Journal of International Law, summer, Vol. 84(2).

\section{Copyright and License}

This article is published under the terms of the Creative Commons Attribution - NoDerivs (CC BY- ND 4.0) License http://creativecommons.org/licenses/by-nd/4.0/ 